\title{
Skały Lubelszczyzny w budownictwie i architekturze regionu - glaukonit
}

\section{Lucjan Gazda}

\author{
Katedra Geotechniki, Wydziat Budownictwa i Architektury, Politechnika Lubelska, \\ e-mail:l.gazda@pollub.pl
}

Streszczenie: W artykule, który w zamyśle autora jest pierwszym z cyklu omawiającego materiały kamienne i surowce mineralne Lubelszczyzny wykorzystywane na przestrzeni dziejów w budownictwie i architekturze oraz innych działaniach inżynierskich i technologicznych, przedstawiono glaukonityt. Ta charakterystyczna, zielona skała jest stosunkowo mało znana, oszczędnie wymieniana w podręcznikach petrografii i surowców skalnych. Skała ta pojawiła się w architekturze najprawdopodobniej tylko w ziemi chełmskiej w XIII wieku i była wykorzystana wyłącznie do budowy I fazy stołecznego Chełma. Później nie była już wykorzystywana i mało znane stały się miejsca jej występowania i pozyskiwania. Skała ta pozwalała na wykonywanie, w porównaniu do innych skał Lubelszczyzny, dużych formatowych bloków oraz obróbki kamieniarskiej o stosunkowo wyrazistych reliefach oraz skomplikowanych kompozycjach. Gwarantowało to możliwość realizacji założeń ideowych pierwszych kamiennych budowli romańskich na obszarze między Wisłą i Bugiem i to od razu w dojrzałym wydaniu stylistyki XII-wiecznej szkoły pizańskiej. Analiza petrograficzna i materiałowa tego unikatowego surowca kamiennego i śladów jego wystąpień złożowych pozwala w przybliżeniu lokalizować historyczną eksploatację glaukonitu oraz inne rejony występowania tej skały. Na podstawie dostępnych obiektów budowlanych i architektonicznych oraz narzędzi możliwa jest wstępna rekonstrukcja warsztatu kamieniarskiego oraz architektury XIII- wiecznych założeń sakralnorezydencjonalnych Wysokiej Górki w Chełmie.

Słowa kluczowe: surowce skalne, glaukonityt, Lubelszczyzna, architektura romańska.

\section{Wstęp}

Glaukonityt jest skałą o konstytucji nie pozwalającej na jednoznaczną klasyfikację petrograficzną. Jedynymi pewnymi elementami jest to, że jest skałą litą oraz zawiera w swojej strukturze minerał glaukonit. Według definicji Słownika petrograficznego glaukonityt jest to skała osadowa zawierająca ponad 50\% glaukonitu [1]. Klasyczna petrografia [2] klasyfikuje glaukonityt, litą skałę o zawartości powyżej 50\% ilastego minerału glaukonitu, do skał żelazistych (zawartość powyżej 15\% Fe), co wynika z dużej zawartości żelaza w strukturze tego minerału. Nigdy jednak nie stanowił glaukonityt źródła żelaza w ramach klasycznych metod metalurgicznych. Glaukonityt, charakterystyczna zielona skała, jest klasyfikowany najczęściej jednak jako odmiana piaskowca, mimo że większość ziaren glaukonitu w tych skałach ma formę nie detrytyczną (okruchową), a autigeniczną. Glaukonit mineralogicznie jest hydromiką o strukturze illitowej, illitowo-montmorillonitowej, nieuporządkowej lub stanowi mieszaninę minerałów ilastych [3]. Tak więc równie dobrze można klasyfikować glaukonityt do specyficznych skał ilastych. Spoiwem glaukonitytów jest najczęściej krzemionka, kalcyt, w mniejszej 
ilości zeolity [4]. Tak więc odpowiednio przy mniejszej od 50\% zawartości glaukonitu, skała ta może przybierać postać gezy, opoki glaukonitowej lub czertu glaukonitowego. Nie jest jednak ambicją artykułu rozstrzygnąć o prawidłowym i jednoznacznym usytuowaniu glaukonitytu w systematyce skał osadowych. Ta niejednoznaczność systematyczna dodaje jej dodatkowej unikatowości, a właśnie ta unikatowość i rzadkość występowania tej skały jest głównym asumptem do powstania tej pracy.

Glaukonityt jest najprawdopodobniej najrzadziej występującą skałą w historycznych budowlach i detalach architektonicznych, a na pewno w zabytkowych budowlach na terenie Polski. Nie jest notowany w artefaktach archeologicznych wcześniejszych, przed budowlanych okresów rozwoju cywilizacji na terenach współczesnej Polski, mimo swoich niewątpliwych walorów estetycznych oraz możliwości uzyskiwania z glaukonitytu np. ochry (po przepaleniu), która towarzyszyła człowiekowi od zarania dziejów. O ile większość surowców kamiennych odkrywała swoje właściwości technologiczne i użytkowe w ciągu tysięcy lat stosowania do różnych celów, zanim utrwaliła się jako kamień budowlany, to glaukonityt takich doświadczeń nie przeszedł. W tym kontekście za fenomenalne należy uznać pojawienie się tego kamienia w architekturze XIII wieku ziemi chełmskiej. Plastycznie ilustruje to zapis latopisu halicko-wołyńskiego, będącego kroniką dokonań militarnych, politycznych i gospodarczych Romanowiczów: „....wzniósł także Daniel cerkiew św. Jana Złotoustego, piękną i wspaniałą. Drzwi zaś jej dwoje były ozdobione ciosanym kamieniem - halickim białym i zielonym chełmskim..." [5]. Zapisy latopisu potwierdzają prowadzone od ponad stu lat w Chełmie i jego okolicach badania archeologiczne i architektoniczne $[6,7,8,9]$. Objętościowo najwięcej glaukonitytu użyto do budowy monumentalnego zespołu rezydencjonalno-sakralnego na Górze Katedralnej w Chełmie. O ilości wykorzystanego tu glaukonitytu mogą świadczyć użytkowe poziomy na dużych powierzchniach wykonane wyłącznie z destruktów powstających przy jego obróbce oraz poziomy równowiekowych aluwiów doliny Uherki, silnie wzbogacone w glaukonit zmywany z placów budów na Górze Katedralnej (badanie własne niepublikowane). Zespół ten powstał w pierwszej połowie XIII wieku, a uległ zniszczeniu już w 1256 roku. Odbudowany pod koniec tego wieku, już jednak bez ,glaukonitytowego przepychu” był przebudowywany i użytkowany do XIV/XV wieku, następnie teren ten był kilkakrotnie niwelowany oraz nadbudowywany nowożytnymi obiektami. Sytuacja ta spowodowała, że przed podjęciem badań archeologicznych całe wzgórze (pod koniec XIX wieku) uznawano za zbudowane w sensie geologicznym z glaukonitytu, a i współcześnie prowadzone badania nie rozstrzygają jednoznacznie o lokalnym (in situ) pochodzeniu tego kamienia [8,9] na Górze Katedralnej w Chełmie. Glaukonityt w skromniejszych ilościach pojawił się także, w formie niewielkich detali architektonicznych, w równowiekowych budowlach okolic Chełma: cerkwi Spasa w dzisiejszym Podgórzu na Pagórze Janowskim, a także w sytuowanych w dolinach morfologicznych, wieżach w Stołpiu i Bieławinie. O efektowności architektonicznej budowli z glaukonitytu świadczą aktualnie jedynie zachowane bazy kolumn, fragmenty archiwolt, portali i inskrypcji udostępnione badaniami archeologicznymi na Górze Katedralnej w Chełmie [6, 9]. Glaukonityt w formie złożowej występuje w kilku lokalizacjach [10], jednak jego zasoby w sensie dostępności eksploatacyjnej należy uznać za całkowicie wyczerpane w ramach XIII-wiecznego przedsięwzięcia budowlanego. Na terenie Lubelszczyzny glaukonityt oprócz Chełma i jego okolic znany jest także z innych lokalizacji, między innymi z Lublina, ale głównie z wierceń i podpowierzchniowych wystąpień oraz z Niziny Lubartowskiej, gdzie jednak ma zupełnie inną postać i genezę [11]. Nie ma materialnych śladów i przekazów o ich eksploatacji oraz architektoniczno-budowlanym wykorzystaniu w innych budowlach Lubelszczyzny niż XIII-wieczne budowle Chełma i okolic. 


\section{Występowanie glaukonitytów na Lubelszczyźnie}

Głównym przedmiotem badań są glaukonitytowe ciosy i detale architektoniczne oraz ich destrukt udostępnione prospekcją archeologiczną na górze Katedralnej w Chełmie (Rys. 1), a celem nadrzędnym próba określenia źródła pochodzenia tego materiału w romańskich budowlach XIII-wiecznego Chełma.

Ponadto badaniom poddano glaukonityty ze znanych z literatury [12] lub własnych prospekcji terenowych autora, naturalnych wystąpień w Stawskiej Górze (Rys. 2a.), Janowie-Podgórzu k. Chełma (Rys. 2b), Lublina (Rys. 2c.) i Górki Lubartowskiej (Rys. 2d.). Wszystkie glaukonityty z przywołanych lokalizacji są skałami paleoceńskimi (eocen oligocen).

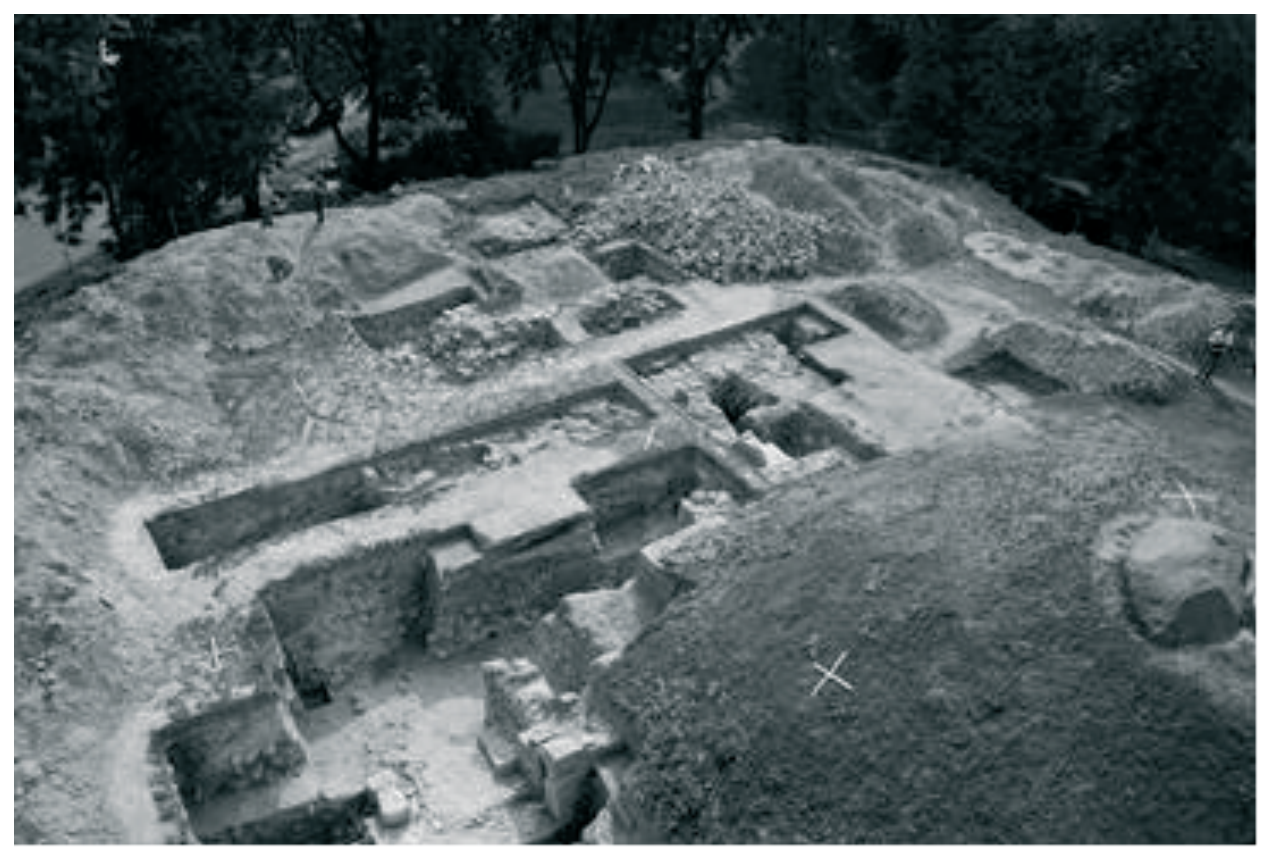

Rys. 1. Widok na odkryte relikty architektoniczne (na pierwszym planie brama wjazdowa do palatium) w trakcie badań wykopaliskowych na Wysokiej Górce w latach 2010 - 2011 (fot. M. Bogacki)

Najbardziej znanym i nagłośnionym miejscem występowania glaukonitytu na Lubelszczyźnie jest Wysoka Górka w Chełmie. Wynika to głównie ze stwierdzonych tu dużych ilości destruktu glaukonitytowego, fragmentów murów oraz spektakularnych detali architektonicznych wykonanych $\mathrm{z}$ tego surowca skalnego. Dotychczas brak jest jednoznacznych przesłanek geologicznych o pochodzeniu tak dużej ilości tego materiału, a tym bardziej o możliwości występowania glaukonitytu in situ.

Więcej argumentów przemawia, że mamy tu do czynienia z lapidarium, w znacznej części utworzonym $\mathrm{z}$ destruktu glaukonitowego nagromadzonego $\mathrm{w}$ trakcie procesu budowlanego i niszczenia obiektów w trakcie awarii i przebudów. Nie można jednak wykluczyć, że skała ta występowała tu w postaci izolowanego płata o niewielkiej powierzchni, podobnie jak występujący cienki poziom glaukonitytowy na Stawskiej Górze [12], lub wyeksploatowana pokrywa glaukonitytowa w lokalnej strukturze tektonicznej Janowa-Podgórza k. Chełma. 
a)

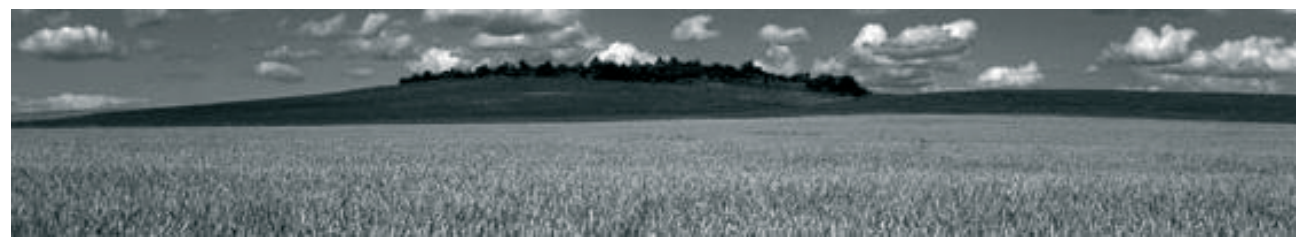

b)

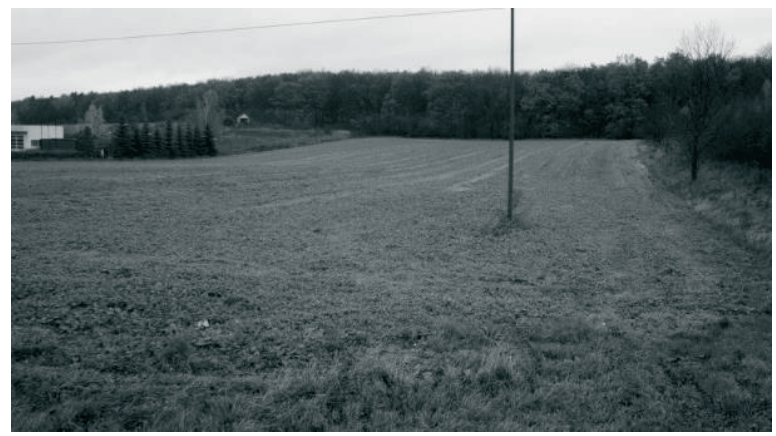

c)

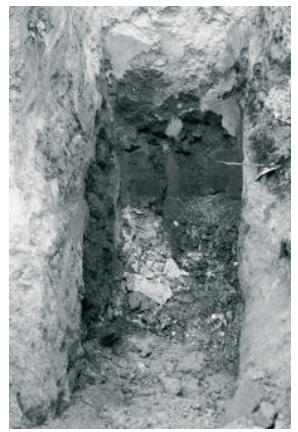

d)

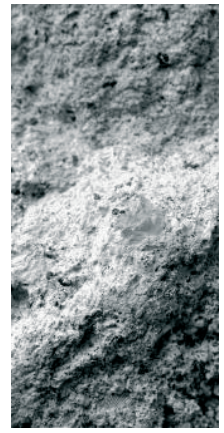

Rys. 2. Występowanie glaukonitytu na Lubelszczyźnie: a) Stawska Góra, b) Janów-Podgórze k. Chełma, c) Lublin - Wrotków, glaukonityt w wykopie fundamentowym, d) glaukonityt z Górki Lubartowskiej

W Stawskiej Górze glaukonityt występuje cienką warstwą do $1 \mathrm{~m}$ na opokach kredowych początkując w formie tzw. twardego dna sedymentację wyżej leżących gez paleoceńskich [12]. Jeszcze w latach 80-tych XX wieku czytelne były tu w morfologii terenu wyrobiska, które mogły świadczyć o powierzchniowej, a nawet podziemnej eksploatacji glaukonitytu (obserwacje własne). Aktualnie dostępny jest do obserwacji jedynie wąski pas rumoszu glaukonitytowego przebiegający wzdłuż krawędzi pola ornego graniczącego tu z rezerwatem stepowym Stawska Góra [Rys. 2 a.].

W Janowie-Podgórzu k. Chełma istnieje wyraźnie zarysowane w morfologii wyrobisko o powierzchni ok. 2 ha wykorzystywane częściowo jako pole orne, a częściowo zabudowane jest obiektami usługowymi [Rys. 2b]. Analiza terenowa poparta znaleziskami fragmentów glaukonitytów oraz informacje o stwierdzanym glaukonitycie w wykopach fundamentowych z lat 90-tych XX wieku jednoznacznie potwierdzają powierzchniowe występowanie tu tej skały. Najprawdopodobniej została ona całkowicie wyeksploatowana.

Stawska Góra i Janów-Podgórze są najbardziej przekonującymi źródłami ciosów glaukonitytowych wykorzystywanych w budowlach Wysokiej Górki. Nie wykluczone, że dalsze badania udokumentują inne lokalizacje, szczególnie, że w sąsiedztwie Chełma istnieje kilka miejscowości, których toponimia związana jest z kamieniem (np. Kamień, Kamionka).

Całkowicie dotychczas nieznane i nie uwzględniane w dokumentacjach kartograficznych [13] jest stwierdzone występowanie cienkich warstw glaukonitytu w obrębie skał paleocenu (gezy) prawobrzeżnego Lublina. W 2016 roku autor udokumentował występowanie tej skały w wykopach fundamentowych dzielnicy Dziesiąta (Rys. 2c). Sposób odsłonięcia nie pozwalał na ocenę wartości surowcowych i złożowych glaukonitytu. Makroskopowo jest to skała soczyście zielona, podobna do glaukonitytów chełmskich. Nie stwierdzono też powierzchniowych wyrobisk mogących świadczyć o historycznej eksploatacji tego kamienia. W sąsiedztwie tej lokalizacji istnieją liczne ślady eksploatacji gezy stosowanej w historycznym budownictwie Lublina. 
Nietypowe glaukonityty, bo bardzo twarde, zbliżone do piaskowców kwarcytycznych stwierdzono w wierceniach rejonu Górki Lubartowskiej (fot. 2d). W profilach wiertniczych są to 1 do 3 poziomów, $15-20 \mathrm{~cm}$ grubości szaro-zielonej skały występującej w stropie luźnych osadów eocenu górnego, formacji bursztynonośnej Lubelszczyzny [11]. Głębokość występowania tych skał $(10-15 \mathrm{~m})$ oraz położenie poniżej poziomu wodonośnego wyklucza jednak możliwość ich eksploatacji w przeszłości. Brak jest tych skał w znanych budowlach i lapidariach regionu.

\section{Metodyka badań}

Glaukonityt nie był dotychczas przedmiotem badań surowcowych i materiałowych. Poza informacjami ogólnopetrograficznymi brak jest w istniejącej literaturze jego charakterystyk surowcowych i materiałowych. Mała dostępność tej skały i właściwie tylko w formie zabytków i destruktów ogranicza możliwość wykonania badań normatywnych. W pracy wykorzystano jedynie makroskopowe (terenowe i laboratoryjne) oraz instrumentalne badania petrograficzne i mineralogiczne do celów porównawczych glaukonitytów z różnych wystąpień. Wykonano badania mikroskopowe płytek cienkich przy użyciu mikroskopu polaryzacyjnego oraz badania fazowe przy użyciu mikroskopu skaningowego. Badania wykonano w laboratorium WBiA Politechniki Lubelskiej. Ocenę właściwości fizykomechanicznych i użytkowych ustalono jedynie na podstawie cech makroskopowych skały w naturalnych wystąpieniach geologicznych oraz zabytkach i destruktach Wysokiej Górki w Chełmie.

\section{Petrografia i właściwości glaukonitytów z Lubelszczyzny}

Można wyróżnić dwa odmienne rodzaje glaukonitytów występujących na Lubelszczyźnie. Są to starsze (górno eoceńskie), bardzo twarde, o spoiwie krzemionkowokwarcytycznym glaukonityty z eocenu górnego Niziny Lubartowskiej (Górka Lubartowska) oraz miękkie glaukonityty eoceńsko-ologoceńskie o spoiwie krzemionkowowęglanowym Wyżyny Lubelskiej (Lublin) i Pagórów Chełmskich (Stawska Góra, JanówPodgórze i Chełm?).

Glaukonityty z rejonu Górki Lubartowskiej przywołuje się tutaj, mimo, że nie były one dotychczas eksploatowane oraz użytkowane, ze względu na ich szczególną genezę oraz właściwości mechaniczne. Kontekst geologiczny ich występowania wskazuje na ich związek ze zdarzeniem impaktytowym w górnym eocenie [11], które nadało im szczególnych właściwości. Glaukonityty te są piaskowcami kwarcowo-glaukonitowymi (ok. 50\% i powyżej glaukonitu) lub piaskowcami kwarcowymi z glaukonitem (mniej niż 50\% glaukonitu) o spoiwie krzemionkowym rekrystalizacyjnym i regeneracyjnym (Rys. 3). Mają one dużą twardość, małą porowatość i cechy zbliżone właściwościami do twardych piaskowców ordowickich z glaukonitem znanych z terenu Polski, z Gór Świętokrzyskich lub eratyków skandynawskich.

Dostępność tych skał wyłącznie z wierceń uniemożliwia określenie ich właściwości surowcowych i użytkowych. Niewielka ich miąższość pozwala sądzić, że o ile będą dostępne z chwilą podjęcia eksploatacji glaukonitu i bursztynu (luźne osady formacji eocenu górnego), to mogą one jako odpad stanowić surowiec do produkcji twardych kruszyw łamanych, deficytowych na Lubelszczyźnie. Mniej prawdopodobnym wydaje się możliwość uzyskania kamienia blocznego, chociaż właściwości wskazują, że może to być surowiec kamienny o właściwościach polernych. 
a)

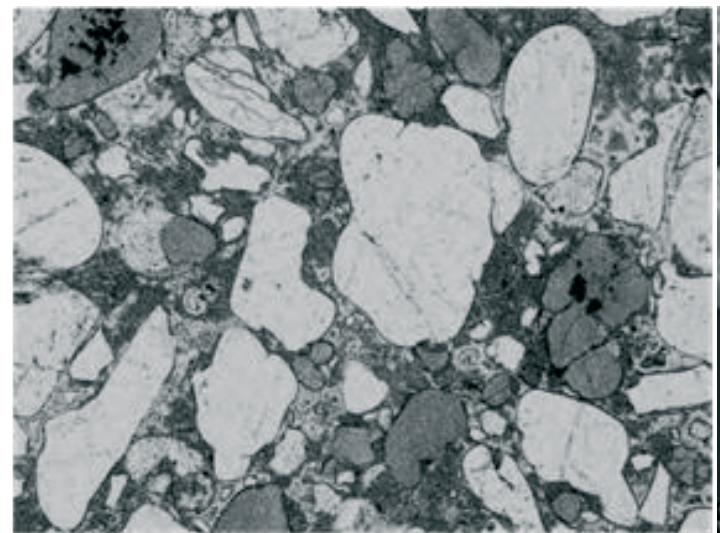

b)

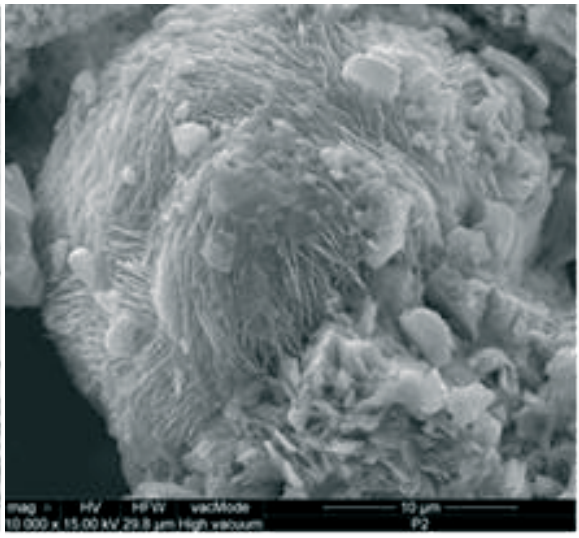

Rys. 3. Glaukonityt/piaskowiec z glaukonitem z Górki Lubartowskiej: a) obraz z mikroskopu optycznego (nikole równoległe), b) mikrofotografia SEM ziarna glaukonitu obrastającego rekrystalizującą krzemionką

Glaukonityt z rejonu Chełma i podobny makroskopowo do nich glaukonityt z Lublina są skałami stosunkowo miękkimi. Są to piaskowce glaukonitowe (do 80-90 \% glaukonitu) o spoiwie węglanowo-krzemionkowym.

a)

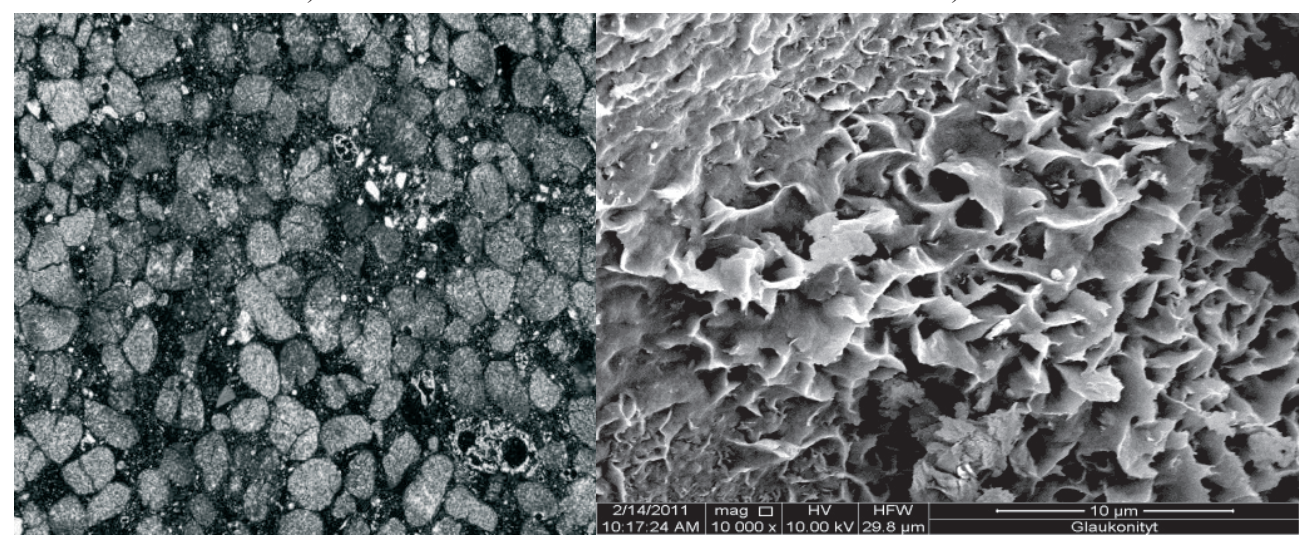

Rys. 4. Glaukonityt z Janowa-Podgórza: a) obraz z mikroskopu optycznego (nikole skrzyżowane), b) mikrofotografia SEM gąbczastego ziarna glaukonitu

W rejonie Stawskiej Góry i Lublina są one lekko zlepieńcowate, co wynika z zawartości w ich strukturze fragmentów opoki i gezy oraz bioklastów kalcytowych i dobrze zachowanych skamieniałości. W rejonie Janowa-Podgórza glaukonityty są jednolicie piaszczyste, intensywnie zielone, z małą ilością drobnoziarnistego detrytycznego kwarcu i klastów węglanowych (Rys. 4). Glaukonity eoceńsko-oligoceńskie, zarówno z Lublina jak i okolic Chełma są stosunkowo miękkie, łatwe w obróbce, porowate, nasiąkliwe a ich zachowanie w destruktach Wysokiej Górki wskazuje na niską mrozoodporność i trwałość w warunkach zmiennych wilgotnościowo. 


\section{Kamieniarka i architektura z glaukonitytu}

Wieloletnie badania archeologiczne na Wysokiej Górce w Chełmie (Rys. 1) - wzgórza w większości intencjonalnie uformowanego, odkryły obwodowy mur prostokątnego założenia o wymiarach 22,5 x $33 \mathrm{~m}$, z bramą w części północno wschodniej (faza I), a wewnątrz fundamenty $\mathrm{z}$ kamienia trzech budowli (faza II) [8, 9]. O właściwościach technicznych i estetycznych glaukonitytów z rejonu Chełma świadczą udostępnione badaniami archeologicznymi ciosy $\mathrm{w}$ zachowanym fragmencie bramy wjazdowej (Rys. 5a) wykonanej w technice opus quadratum bez zaprawy oraz w obrębie murów obwodowych wykonanych w technice opus emplectum z użyciem zaprawy wapiennej (Rys. 5b).

a)

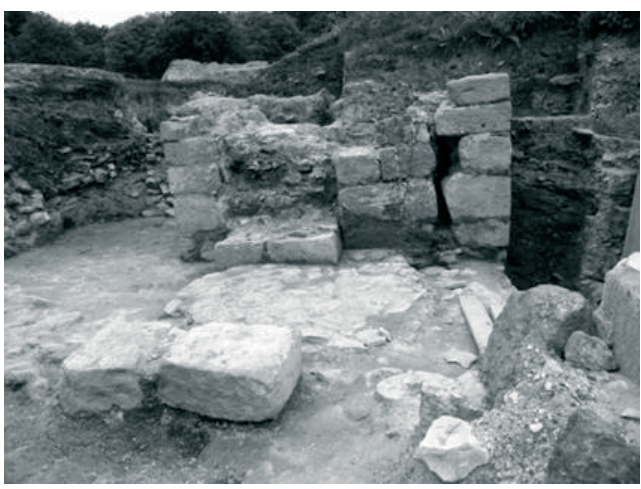

b)

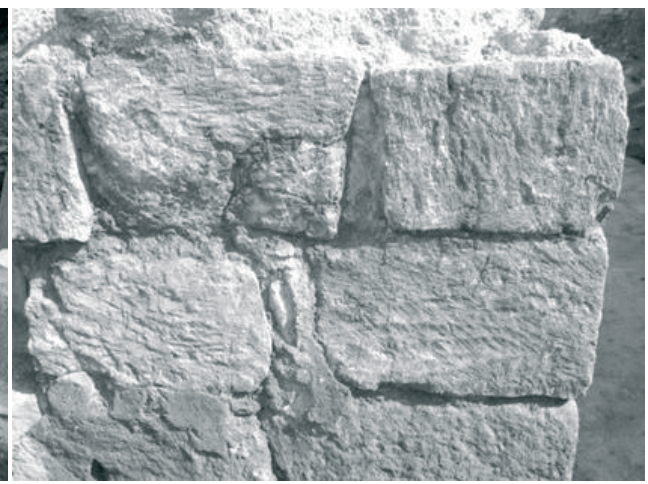

Rys. 5. Zachowane relikty budowli „glaukonitytowych”: a) brama wjazdowa do pallatium; b) fragment muru obwodowego licowanego glaukonitytem (fot. S. Gołub)

Wewnątrz założenia zarejestrowano jednolity wyrównany poziom użytkowy w postaci zielonego piasku glukonitytowego, będącego najprawdopodobniej destruktem z obrabianych tu ciosów i detali. W partiach licowych: wewnętrznej i zewnętrznej, zastosowano dobrze dopasowywane w wątku poziomym bloki glaukonitytowe. Miały one różne wymiary: 40x25x20 (dł. x szer. x wys.), 33×34x23, czy 37x23x22, przy czym zbliżoną średnią wysokość od 20 do $23 \mathrm{~cm}$. Wysokość może odpowiadać w przybliżeniu max. grubości poziomej (uławiceniu glaukonitytów) bloczności złoża. Narożniki muru obwodowego oraz bramy wjazdowej były bardzo starannie opracowane powierzchniowo i doskonale dopasowane, co pozwoliło na wykonanie tych obiektów w rzymskiej technice opus quadratum. Wewnątrz założenia zlokalizowane mury fundamentowe budowli II fazy zabudowy Wysokiej Górki wykonano jednak już w odmiennych technikach budowlanych oraz z innych surowców. W fundamentach tych obiektów zarejestrowano wtórne użycie wysokiej klasy detali wystroju architektonicznego wykonanych z glaukonitytu oraz kilku prostopadłościennych ciosów. Rezygnacja z wykorzystania glaukonitytu w II fazie budowy (odbudowy?) może być efektem całkowitego wyczerpania zasobów tego surowca, co potwierdzają inwentaryzacje wystąpień tej skały w okolicach Chełma (badania własne), lub co jest mniej prawdopodobne, negatywne doświadczenia w zachowaniu się tego kamienia w użytkowaniu. Predyspozycje materiałowe najlepiej czytelne są w detalach cyzelowanych w glaukonitycie (Rys. 3 i 4). O właściwościach materiałowych glaukonitytu świadczą detale architektoniczne wydobyte na początku XX wieku przez A. Pokryszkina (Rys. 6) i w trakcie ostatnich sezonów archeologicznych zespołu A. Buko (Rys. 7, 8, 9,10). Jest to skała 
o ciekawych, unikatowych wśród materiałów kamiennych, walorach estetycznych, technicznych i stosunkowo łatwa w obróbce, co pozwalało na wykonywanie glifów i reliefów o stosunkowo skomplikowanych kompozycjach.
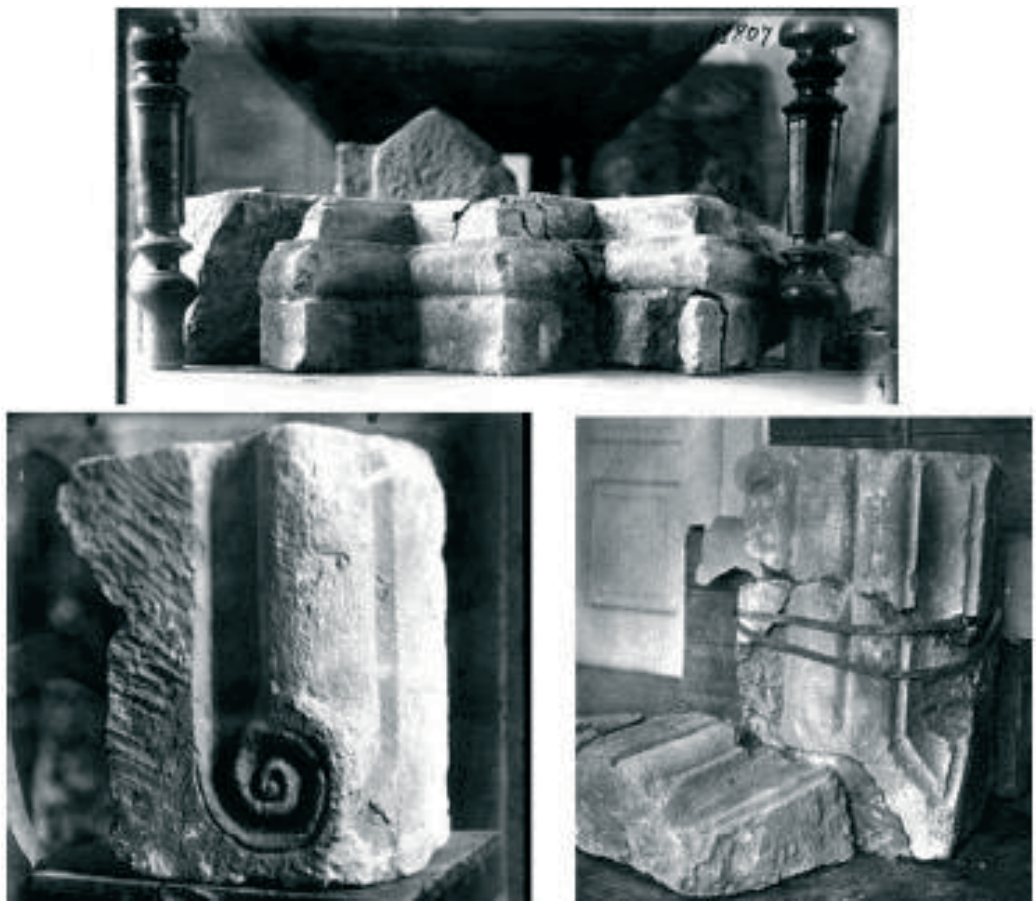

Rys. 6. Detale architektoniczne z badań P. Pokryszkina (fot. P. Pokryszkin, Archiwum Instytutu Historii Kultury Materialnej RAN w Sankt-Petersburgu)

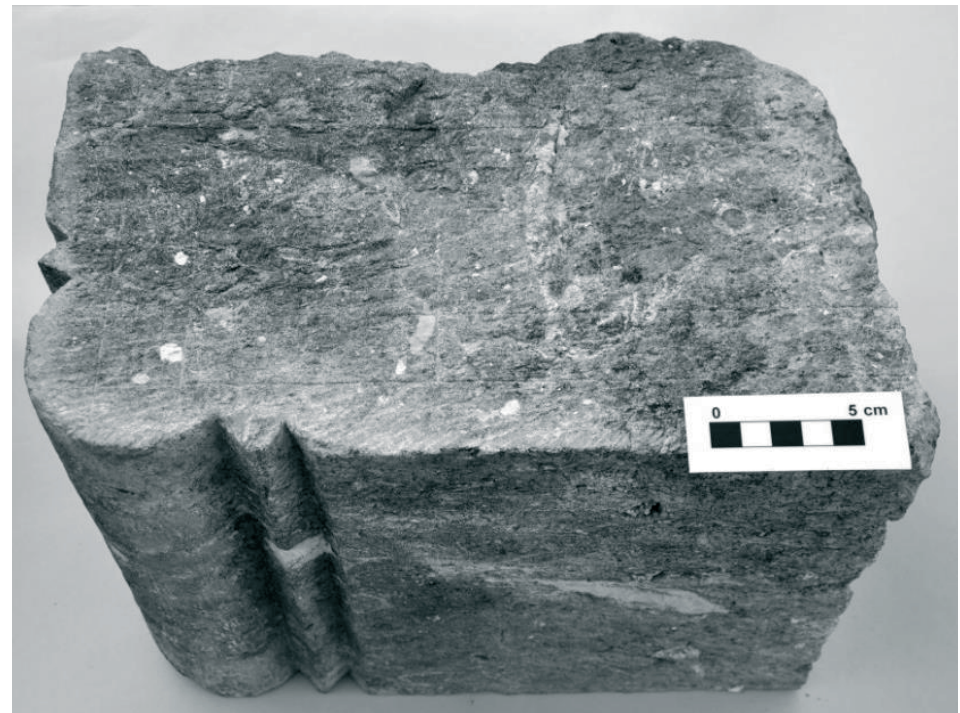

Rys. 7. Glaukonitytowy detal architektoniczny z nieznanego portalu z rytym rysunkiem technicznym (tzw. babilon) (fot. S. Gołub) 
a)

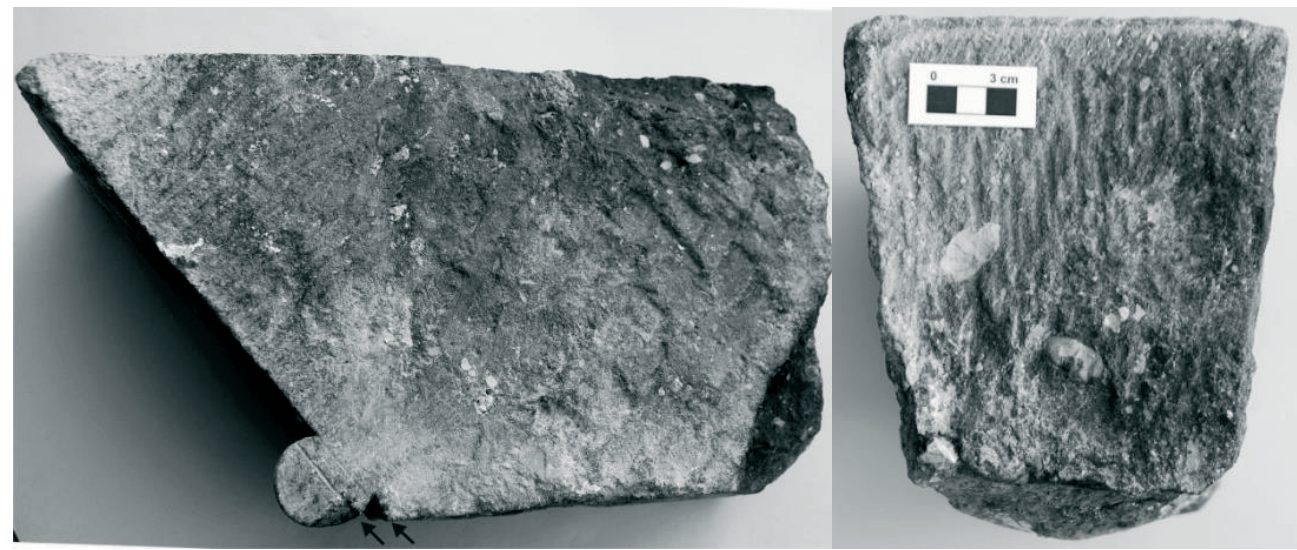

Rys. 8. Glaukonitytowe detale: a) kształtowy element z wyraźnie wykreślonymi liniami domierzającymi kształtowanie pionowego wałka; b) klin (zamek ?) z nieznanego sklepienia budowli (fot. T. Sławiński, S. Gołub)

Pochodzą wyłącznie z destruktów i nie odnaleziono dotychczas ich jednoznacznego kontekstu w konstrukcji obiektów pierwszej fazy zabudowy XIII-wiecznego (sprzed 1236 roku wg. A.Buko) zespołu architektonicznego stołecznego Chełma, może jedynie z wyłączeniem archiwolty precyzyjnie rzeźbionej i geometrycznie dociętej. Precyzja wykonania i stan zachowania pozwoliły na zwymiarowanie tego elementu i umieszczeniu w rekonstrukcji portalu bramy wjazdowej do palatium Daniela Romanowicza (Rys. 9 ).

a)
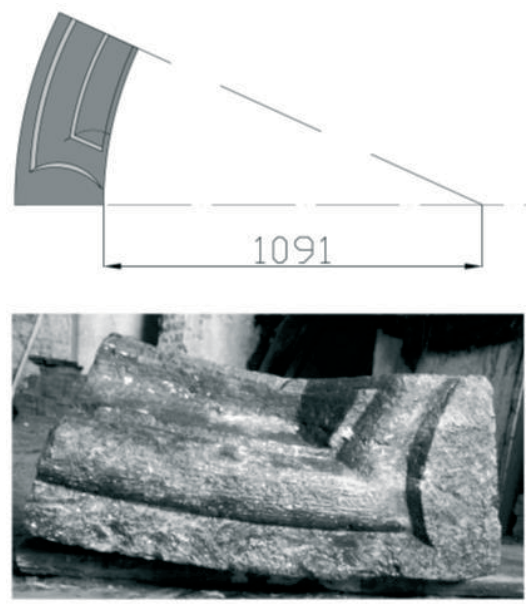

b)

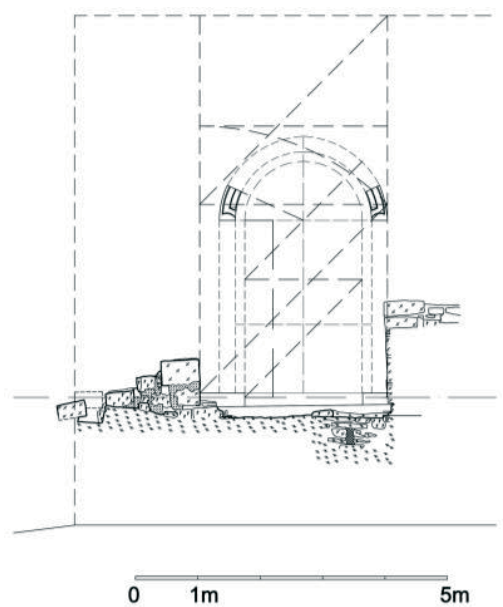

Rys. 9. Rekonstrukcja architektoniczna portalu glaukonitytowego bramy wjazdowej: a) łukowy detal architektoniczny i wyznaczenie promienia łuku, b) wpasowanie portalu w relikty bramy wjazdowej (fot., analiza i rekonstrukcja V. Petryk)

Otwartym pozostaje, czy był on jednolicie zielony, czy biało-zielony, co wynika z zapisów latopisu halicko-wołyńskiego, odniesionego do jednej z budowli sakralnych (cerkwi pw. św. Jana Złotoustego. Glaukonityt, „zielony kamień chełmski” był łączony z białym alabastrem, „kamieniem halickim”. W porównaniu do innych rodzajów piaskowców, 
glaukonityt charakteryzuje się przy podobnych właściwościach spoiwa, stosunkowo miękkimi ziarnami. Ziarna, obok miękkich klastów i bioklastów skał kredowych (opoka, geza), to w $80 \%$ minerał ilasty glaukonit, wykształcony w formie sferycznej, o charakterystycznej, agregatowej strukturze wewnętrznej (Rys. 3 i 4). Przy wykuwaniu lub przecinaniu formatów lub detali, pozwala to na dzielenie ziaren, a nie tak jak w przypadku piaskowców kwarcowych wykruszaniu ziaren w płaszczyźnie obróbki. W efekcie materiał ten zachowuje się bardziej plastycznie, przy zbliżonych do większości piaskowców parametrów wytrzymałościowych. Na powierzchniach tych detali z XIII-wiecznych doskonale czytelne ślady obróbki, zbieżne traseologicznie ze znalezionymi narzędziami kamieniarskimi (Rys. 10). Powtarzalność sposobów obróbki i uzyskiwanej stylistyki kamieniarki może być dobitnym potwierdzeniem zapisów latopisu halicko-wołyńskiego [5] o pewnym mistrzu Awdieju, który tu pracował przy obróbce kamienia.

a)

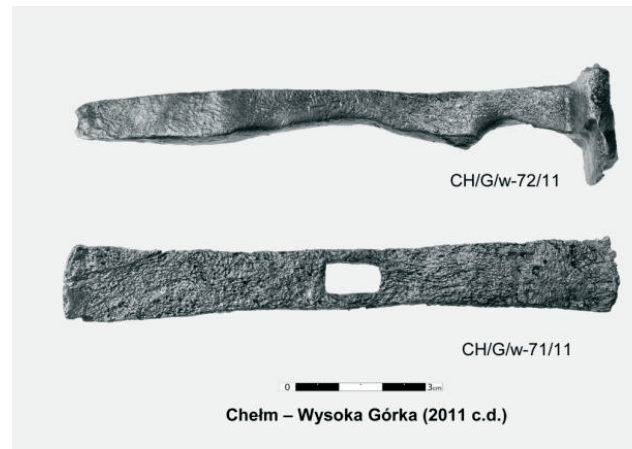

b)

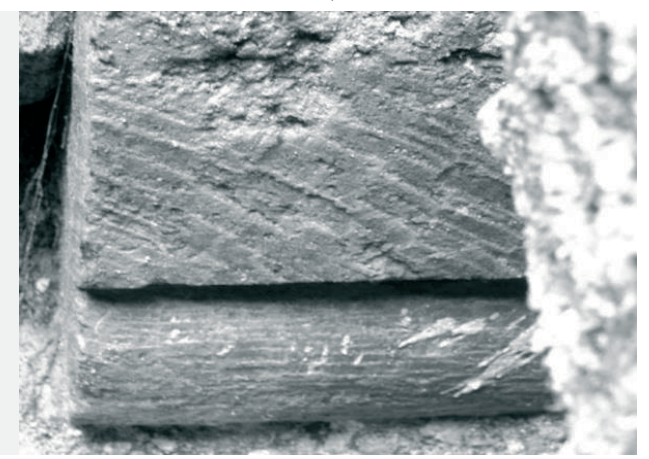

Rys. 10. Warsztat mistrza Awdieja?; a) narzędzia z żelaza po konserwacji (fot. G. Zabłocki), b) ślady obróbki na detalu glaukonitytowym (fot. S. Gołub)

Powierzchnie i krawędzie reliefów udostępnionych detali glaukonitytowych nie wykazują śladów użytkowania. Na obecnym etapie badań $[8,9]$ zakłada się, że pierwsza faza zabudowy Wysokiej Górki, którą możemy określić glaukonitytową, uległa szybkiej destrukcji konstrukcyjnej, nie wykluczone że w ramach katastrofy budowlanej. Pierwsza faza zabudowy rezydencjalno-sakralnej Wysokiej Górki była zarazem jedynym epizodem wykorzystania glaukonitytu w ziemi chełmskiej i na Lubelszczyźnie. Aktualnie, poza sezonami archeologicznymi i zabytkami zgromadzonymi w muzeum, glaukonityt w formie tej historycznej kamieniarki można oglądać w Chełmie, w ogrodzeniu Góry Katedralnej (Rys. 11) stanowiącego swoistego rodzaju lapidarium glaukonitytu i XIII-wiecznej glaukonitytowej przeszłości miasta.

Łączenie zielonego glaukonitytu z bielą alabastru było działaniem ideowym, nawiązującym do symboliki architektury Bizancjum, Europy Karolingów, a najbardziej wyraziście do biało -zielonych budowli Toskani w wydaniu tzw. szkoły pizańskiej [14] z XII/XIII wieku. Zielony serpentynit i białe marmury Toskani okazały się jednak zdecydowanie trwalsze od glaukonitytu i alabastru, co pozwoliło na przetrwanie tych budowli, a nawet na kontynuację tej stylistyki w następnych wiekach.

Jak istotnym było to biało-zielone przesłanie dla kultury epoki może świadczyć, że po destrukcji (pożar, katastrofa budowlana) pierwszej fazy zabudowy Chełma usilnie poszukiwano twardych białych i zielonych kamieni. Zarejestrowane jest to na Wysokiej Górce w formie „alchemicznej” petryfikacji lokalnej kredy piszącej (sztuczne kamienie białe) oraz z dodatkiem destruktu glaukonitowego (sztuczne kamienie zielone) [14]. Destrukt glauko- 
nitytowy wykorzystywano tu także do sporządzania zielonych zapraw oraz pigmentu do malowania ścian.
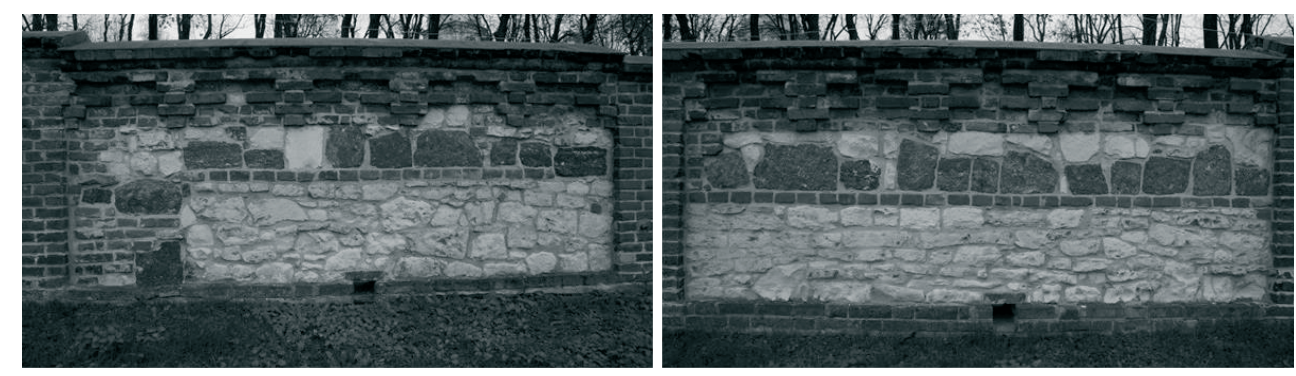

Rys. 11. Lapidarium glaukonitytu (fot. L. Gazda)

\section{Podsumowanie i wnioski}

Glaukonityt, charakterystyczna zielona skała pojawiła się w architekturze na Lubelszczyźnie tylko w ziemi chełmskiej i tylko wyłącznie w XIII wieku. Glaukonityt jest zieloną skałą o ciekawych, unikatowych wśród materiałów kamiennych, walorach estetycznych i technicznych, co pozwalało na wykonywanie dużych ciosów oraz glifów i reliefów o stosunkowo skomplikowanych kompozycjach podkreślanych różnymi odcieniami zieleni. Analiza petrograficzna i materiałowa tego unikatowego surowca kamiennego i jego wystąpień złożowych pozwala sądzić o kilku lokalizacjach historycznej eksploatacji, głównie w rejonie Stawskiej Góry oraz Janowa-Podgórza k. Chełma. w rejonie. Nie wyjaśniona jednoznacznie pozostaje możliwość występowania tej skały w podstawie nasypów i obiektów Wysokiej Górki w Chełmie. Udokumentowane współcześnie występowanie glaukonitytu w Lublinie oraz na Nizinie Lubartowskiej najprawdopodobniej nigdy nie były eksploatowane, a tym bardziej materiały te nie były użyte w budownictwie i architekturze Lubelszczyzny. Glaukonityt jako surowiec i materiał ma współcześnie na Lubelszczyźnie wymiar jedynie symboliczny i emocjonalny, bardzo ważny dla historii rozwoju budownictwa i architektury kamiennej terenów na wschód od Wisły. Powinno to być istotnym elementem do działań w ramach tworzenia w Polsce i Europie szlaków geoturystycznych, wiążących lokalne surowce mineralne, a szerzej geologię, z budownictwem regionu. Geoturystyka jest formą turystyki bazującej na obiektach geologicznych (w tym przypadku wystąpienia unikatowych glaukonitytów na Lubelszczyźnie), która fantastycznie uzupełniana jest dokonaniami historycznego budownictwa i architektury (XIII wieczna zabudowa Chełma i okolic). Unikatowość skały i dokonania budowlane z jej użyciem dają podstawy do rozważenia dla tego rejonu koncepcji utworzenia obiektu o randze Geoparku UNESCO.

\section{Literatura}

1. $\quad$ Ryka W., Maliszewska A., Stownik petrograficzny. Wyd. geologiczne, 1991, 118.

2. Bolewski A., Parachoniak W., Petrografia. Wyd. Geologiczne, 1974, 341-344.

3. Bolewski A., Mineralogia szczegółowa. Wydanie III. Wyd. Geologiczne, 1982, 380-390.

4. Gazda L., Harasimiuk M., Krzowski Z., Litogeneza warstw z glaukonitem w górnej kredzie i paleocenie Pagórów Chetmskich (Wyżyna Lubelska, E Polska). Annales Universitatis Mariae Curie-Skłodowska, Sectio B Geographia, Geologia, Mineralogia et Petrographia 47 (1992) 1-24.

5. Dąbrowski D., Góra Katedralna w Chetmie w świetle źródet pisanych. Archiwum Inst. Arch. i Etnol. PAN w Warszawie, 2013. 
6. Rappoport P., Cholm. Sovietskaja Archeologija 20 (1954) 93-99.

7. Gurba J., Kutyłowska I., Sprawozdanie z badań wczesnośredniowiecznego grodziska w Chetmie Lubelskim. Sprawozdania Archeologiczne 22 (1970) 231-241.

8. Buko A., Dzieńkowski T., Gołub S., Rezydencja ksiązęca na „Wysokiej Górce” w Chetmie w świetle wyników badań archeologicznych z lat 2010-2012. Rocznik Chełmski 16 (2012) 293304.

9. Buko A., Dobrowolski R., Dzieńkowski T., Gołub S., Petryk V., Rodzińska-Chorąży T., Palatium czy zespót rezydencjonalny? Pótnocna czesść Góry Katedralnej w Chetmie (Wysoka Górka) w świetle wyników najnowszych badań. Sprawozdania Archeologiczne 66 (2014) 101-134.

10. Gazda L., Gołub S., Bevz M., Glaukonit - unikatowy materiat budowlany i architektoniczny XIII-wiecznych budowli ziemi chetmskiej. Integracja sztuki i techniki w architekturze i urbanistyce. Wyd. Uczelniane Uniwersytetu Technologiczno-Przyrodniczego w Bydgoszczy, 2015, 127-138.

11. Gazda L., Huber M., Kiebała A., Mendyk E., Kosmiczny epizod lubelskiego bursztynu. Lubelski bursztyn: znaleziska, geologia, złoża, perspektywy; [Red: Gazda L.] Chełm: Państwowa Wyższa Szkoła Zawodowa w Chełmie, Wydawnictwo M w Krakowie, 2016, 94-102.

12. Harasimiuk M., Szwajgier W., Szczegółowa mapa geologiczna Polski 1:50 000 - ark. Siedliszcze (0751). Wyd. Geol., Warszawa, 1996.

13. Butrym J., Harasimiuk M., Henkel A., Szczegółowa mapa geologiczna Polski w skali 1:50 000, arkusz Lublin (0749). Wyd. Geol., Warszawa, 1982.

14. Gazda L., Mykola Bevz., Średniowieczny eksperyment materiałowo-technologiczny przy odbudowie założeń rezydencjalno-sakralnych Daniela Romanowicza w Chetmie. Materiały Budowlane nr 11(543) (2017) 1-5.

\section{Lubelszczyzna rocks in the construction and architecture of the region - glaukonityte}

\section{Lucjan Gazda}

\section{Department of Geotechnics, Faculty of Civil Engineering and Architecture, Lublin University of Technology,e-mail: l.gazda@pollub.pl}

Abstract: The paper, intended as the first one in the cycle discussing Lubelszczyzna's rock materials and mineral raw materials used in construction, architecture and other engineering and technological enterprises in the course of history, looks into glauconite. This characteristic green rock is relatively unknown to the public, rarely mentioned in petrography and rock raw materials handbooks. The rock first appeared in architecture probably only in Chełm Land in 13th century and was used in the 1st phase of the construction of the capital of Chełm. Later, it was no longer in use, and its locations and places of sourcing became quite forgotten. From glauconite large-scale blocks could be produced as well as quite pronounced reliefs and complex compositions. It enabled the implementation of the ideological assumptions of the first Romanesque stone buildings between the Vistula and the Bug Rivers and, moreover, directly in the mature style of the Pisan School of 13th century. A petrographic and material analysis of this unique stone as well as the remains of its deposits make it possible to approximately locate the historical mining sites of glauconite and other areas where it occurred. On the basis of the accessible architectural and other structures as well as tools, a preliminary reconstruction of the stone workshop and architecture of the 13th century sacral-residential complexes of Wysoka Górka in Chełm can be performed.

Keywords: stone resources, glauconityte, Lubelszczyzna, Romanesque architecture. 